\title{
Surface erosion countermeasures incorporating geotextiles
}

\author{
M. Heibaum \\ Federal Waterways Engineering and Research Institute (BAW), Karlsruhe, Germany
}

\begin{abstract}
Nature often demonstrates the power of water to be stronger than soil and vegetation, often even stronger than rock. Even seemingly mild hydraulic load from rainfall can be the reason for severe impact on structures and ground. To achieve erosion mitigation or to hinder erosion at all, either the action of the water has to be reduced or the resistance of the ground and man-made earth structures has to be increased. The first results in controlling, the second in opposing the water. Countermeasures to rainfall runoff are agricultural measures like disking or contour ploughing, or structural measures like terracing or building checks in erosion rills and gullies. Vegetation stabilizes the surface, but may need protection, at least during growth. Countermeasures against flood erosion at the upper bank or due to overtopping of an earth structure are appropriate reinforcement or surface protection. In all cases, well planned measures incorporating geosynthetics can help to achieve the desired stability.
\end{abstract}

\section{INTRODUCTION}

The interaction of water and soil has been both a blessing and a curse in all times. Water is needed for life but is also threatening life when appearing unboundedly. To allow for beneficial use of water as well as to protect the land from flooding, resulting in scour and erosion often special measures are necessary to keep the water within certain bounds. Irrigation canals and water pipelines allow the transport to areas without sufficient precipitation and protective and regulating structures limit the adverse consequences of too much water. In both cases, geosynthetics contribute to the resilience of the structures.

To mitigate the detrimental interaction of water and soil, either the action or effect of the water has to be reduced or the resistance of the ground has to be increased. The first are also called "active" measures while increasing the resistance is a "passive" method.

Active methods are all measures that alter the flow pattern to reduce impact intensity. The aim is to reduce discharge quantity and flow velocity. This can be achieved by infiltration of the water into the ground or by terracing the ground (which needs special measures at the edges). Structural measures to alter the surface flow pattern are elements to divide the runoff or check dams. Drains collect flowing water and allow safe discharge. Impervious elements prevent any interaction of ground and water. Active measures might be the more intelligent way to influ- ence the interaction of ground and water, but often the situation in situ compels to other solutions, in particular if we are confronted to deluge-like quantities of water.

Increasing the resistance is the alternative and often the only measure if no alteration of actions can be realised. Also the comparison of costs may lead to such a decision. Strengthening the ground comprises an increase of the overall stability and/or the surface strength of an earth structure or an increase of the resistance of a single element that is affected by hydraulic action.

In this context, geosynthetics can provide strength and flexibility, imperviousness and drainage, durability and robustness or controlled degradation. All these properties can be of use to handle the many occurrences of interaction of water and ground and to avoid scour and erosion. Impervious elements perform well in this respect by preventing any interaction of ground and water, but such applications are not discussed further in this paper.

In the following, a state-of-the-art overview is given of the origin and development of erosion and the possible countermeasures. Geosynthetic products can contribute in many cases to stability and resilience of protective measures, in most cases as a part of an erosion protection system. 


\section{RAINFALL INDUCED EROSION}

Falling rain causes several effects on the ground, such as compaction, disintegration, detachment, entrainment and deposition. Raindrop impact first compresses, then dislodges soil, which is splashed into the air (therefore called "splash erosion" - Figure 1). The next step is transportation of soil loosened by raindrop splash, resulting in sheet erosion, a removal of soil from sloping land in thin layers, depending on soil type and flow velocity.

Raindrop impact may result in the formation of seal, and subsequently of the crust of soils. Crust is a thin layer at the soil surface characterized by a greater density, higher shear strength, and lower hydraulic conductivity than the underlying soil. Soil seals and crusts can significantly reduce infiltration rate and subsequently increase runoff, which results in soil erosion in other places (Zejun et al. 2002).

The increase of runoff may cause rill erosion. This type of erosion occurs where sheetflow becomes concentrated in small, defined channels that are at the beginning a few centimetres deep, but growing deeper and finally forming gullies.

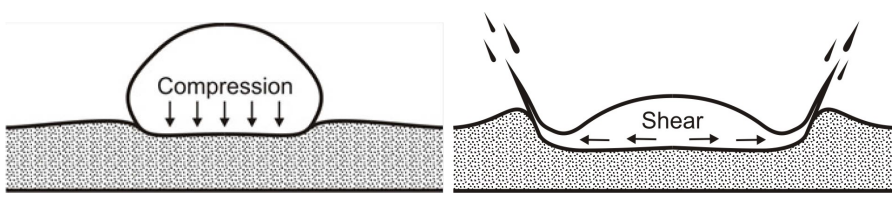

Figure 1. Raindrop impact and splash.

This process is accelerated enormously when the ground is highly saturated due to intense rainfall and therefore unable to absorb any more water. When the flow velocity is further increased or if the flow is concentrated, e.g. due to the local damage of vegetation, channel erosion occurs that may finally lead to failure of an earth structure. So it is desirable to hinder the initiation of erosion at all. There are two approaches to avoid erosion: infiltration and protection. An overview of erosion types and minimization techniques is given in Table 1 (Johnson et al. 2003).

Generally, it is desirable to avoid rainfall induced erosion at all. If eroded soil becomes suspended matter in a water runoff, provisions shall be undertaken to allow for controlled sedimentation. Uncontrolled sedimentation can clog streams, storm drains, and culverts. Rain eroded soil silting up a river can become a significant impact on waterways. Fluvial habitat is endangered, shipping is constrained and costly dredging becomes necessary. Intensified sedimentation can lead to increased flood heights, as sediment raises the level of the riverbed as it settles.

If watercourse siltation cannot be avoided, e.g. when earthworks are performed and surface soil can't be sufficiently protected, silt curtains or silt barriers, also named turbidity barriers or turbidity curtains, are floating flexible sediment control barriers designed to prevent the spread of silt and sediment in water bodies, e.g. when sediment laden stormwater is fed into the water course.

The curtains are constructed of permeable or nonpermeable geosynthetic material. The curtain is suspended vertically in the water with flotation material enclosed in the top pocket and a ballast chain enclosed in the lower pocket. It can be heavily weighted at the bottom to ensure that sediment does not travel under the curtain, or a certain distance to the bottom is left to allow for water flow but to force the sediment down near the bottom.

Table 1. Types of surface erosion (Johnson et al., 2003).

\begin{tabular}{|c|c|}
\hline Type of Erosion & $\begin{array}{l}\text { Minimization } \\
\text { Technique }\end{array}$ \\
\hline $\begin{array}{l}\text { Raindrop splash } \\
\text { (Raindrop impact of the } \\
\text { raindrop dislodges soil, caus- } \\
\text { ing it be splashed into the air. } \\
\text { The splash effect also in- } \\
\text { creases compaction and de- } \\
\text { stroys open soils structure.) }\end{array}$ & $\begin{array}{l}\text { Stabilize the soil to prevent } \\
\text { erosion. } \\
\text { Mulch. }\end{array}$ \\
\hline $\begin{array}{l}\text { Sheet erosion } \\
\text { (Transportation mechanism of } \\
\text { soil loosened by raindrop } \\
\text { splash, removal of soil from } \\
\text { sloping land in thin layers. } \\
\text { Dependent on soil type, depth } \\
\text { and flow velocity.) }\end{array}$ & $\begin{array}{l}\text { Minimize by diverting flow } \\
\text { away from the slope. }\end{array}$ \\
\hline
\end{tabular}

\section{Rill erosion}

(Occurs where sheetflow becomes concentrated in small, defined channels a few $\mathrm{cm}$ deep. Form of erosion in which most rainfall erosion occurs.)

\section{Gully erosion}

(Concentrated flow in unrepaired rills.)

\section{Prevent by slope stabiliza-} tion and diverting flow.

Repair immediately with disking or tilling

\section{Channel erosion}

(Occurs at bends and in constrictive areas.)

Requires extensive repair. Prevent by dispersing and diverting sheetflow.

\section{Smooth bends, add riprap.}

Use of bendway weirs or bioengineering methods.

Erosion countermeasures should be installed as early as possible in the process of erosion, therefore the best way is to hinder the initiation of erosion (step 1). If erosion has started already, measures have to be provided that hinder the accumulation of material transport (step 2), and if there is already a certain sediment flow, it should be guided not to result in detrimental effects (step 3).

During storm events with heavy rainfall, infiltration of excess surface water into the ground is the first choice. Infiltration is supported by vegetation and residue cover that slows down the movement of surface runoff and allows the water to infiltrate. Re- 
sidual roots are also important as these provide channels that allow surface water to seep into the soil. If there is no natural residue, mulching is often proposed (see below).

Tillage and cropping practices directly affect the overall soil erosion susceptibility. Active measures to foster infiltration are disking, contour ploughing or terracing. Similar to local terracing is building checks in erosion rills and gullies. All kinds of checks, including silt fences, will cause a reduction of flow velocity and deposition of sediments. Ponding the water will also increase infiltration, but can be impaired by colmatation of the ground. Therefore deposited material should be removed recurringly.

Also during and after construction processes surface runoff and subsequent erosion is often a problem. A construction process like road building disturbs soil, which is then vulnerable to being washed downstream when it rains. Therefore erosion and sediment control measures and practices are actions often taken on an interim basis pre, during, and post construction to minimize the disturbance, transportation, and unwanted deposition of sediment. If installed temporarily, for many applications also natural fibres can be used. Such fibres will disintegrate after a certain time, but may remain strong enough until the final situation is reached. Even though such measures often are manmade, erosion protection should not detract from the natural environment. Geotextile can help to realize measures that maintain a natural appearance.

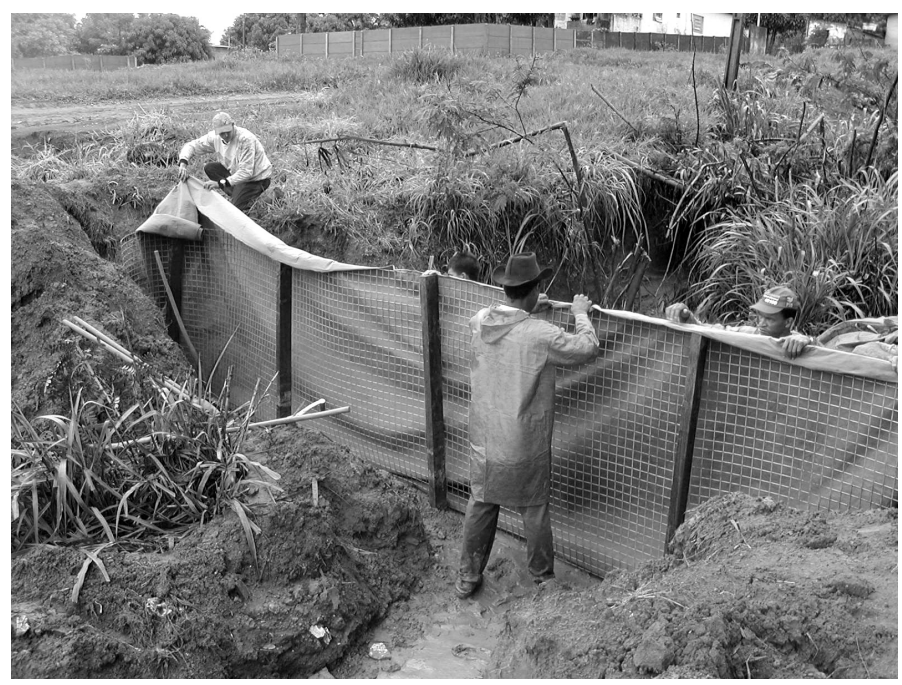

Figure 2. Silt fence in ersosion channel (courtesy R.J.C.Farias).

Silt fences are composed of tough, durable, geotextiles attached to support posts (Figure 2) that screen silt and sand particles from the runoff. With the build-up of sediments behind the fence it acts more as a barrier than a filter, even if in the beginning the trapped soil forms a secondary filter behind the geotextile. The fence reduces the flow velocity which leads to the creation of a pond of relatively still water behind it, acting as a sedimentation basin to collect the suspended soil from the runoff water. The silt fence should provide sufficient storage capacity for a typical storm event. If the suspension volume is completely unknown, overflow outlets should be installed to avoid fence overtopping. The use of light geotextiles in silt fences is particularly interesting because it reduces the costs of the structure. However, the geotextile has also to attend mechanical and survivability requirements for a satisfactory performance (Holtz et al. 1997).

The function of sandbag barriers is similar to that of silt fences, being more robust but usually of lesser height. Sandbags filled with very permeable fill and designed as a filter act in the beginning of the sedimentation process behind the barrier as a filter. The barrier function becomes predominant with increasing sedimentation, as with silt fences. Sandbags barriers are less susceptible to overtopping if the size of the bag is chosen appropriately. Due to the flexibility of the bags, gaps between the single elements are ruled out. When using the traditional straw bales, often concentrated erosion developed at such gaps between the bales.

Geotextile triangular dikes (Figure 3) are made with a foam core and hence are impervious. Their advantage is low weight, so transport up the hills is less tedious.

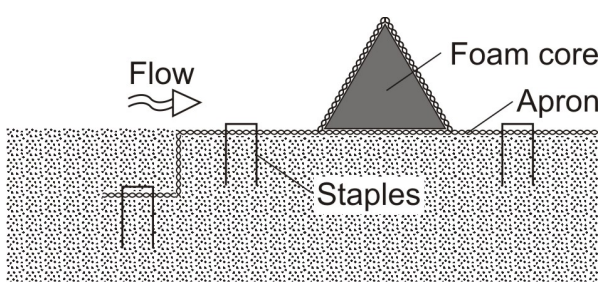

Figure 3. Triangular dike.

Also drains, namely trench drains and near surface interceptor drains reduce the surface rainwater runoff by forcing infiltration and seepage towards the drain from where the water can be discharged safely. The important aspect of a well-functioning drain is to create a large filter surface. For that purpose, the trench shall be sufficiently large, lined by a filter fabric and filled with highly permeable fill material (Figure 4).

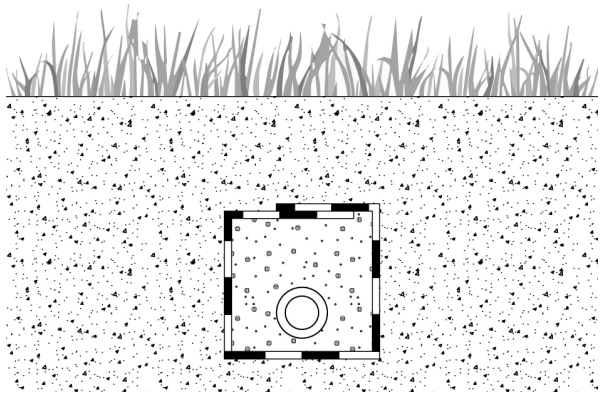

Figure 4. Trench drain with geotextile filter. 
It should be avoided just to wrap a filter fabric around a drain pipe! The filter fabric has to be designed to hold back the surrounding soil and let the water pass easily. Filter design has been addressed in many publications. An overview and the current development is given in Heibaum (2014).

Usually there are no specific design requirements for geosynthetics in erosion protection applications. Certain minimal requirements are given in several handbooks like e.g. "The Erosion and Sediment Handbook" (North Dakota DOT, 2004). Tables 2 and 3 provide an overview over countermeasures according to the steps mentioned and the possible contribution of geosynthetics.

Table 2. Countermeasures to prevent accumulation of material transport.

\begin{tabular}{ll}
\hline $\begin{array}{l}\text { CONTROL } \\
\text { MEASURE }\end{array}$ & GEOSYNTHETIC CONTRIBUTION \\
\hline slope drain & geosynthetic tubing, geotextile filter \\
\hline bale check & confinement (netting) of bales \\
\hline silt fence & geotextile fabric \\
\hline $\begin{array}{l}\text { geotextile } \\
\text { triangular dike }\end{array}$ & $\begin{array}{l}\text { urethane foam elements in woven geo- } \\
\text { textile }\end{array}$ \\
\hline riprap & geotextile filter below riprap layer \\
\hline wattles & netting of straw wattles \\
\hline
\end{tabular}

Table 3. Countermeasures to control sediment flow. CONTROL GEOSYNTHETIC CONTRIBUTION MEASURE

\begin{tabular}{ll}
\hline bale checks & confinement (netting) of bales \\
\hline silt fence & geotextile fabric \\
\hline $\begin{array}{l}\text { geotextile triangular } \\
\text { dike }\end{array}$ & foam elements in woven geotextile \\
\hline riprap & geotextile filter below riprap layer \\
\hline rock ditch checks & geotextile filter below rock \\
\hline sandbag barrier & geosynthetic bag material \\
\hline floating silt curtain & impermeable geosynthetic sheet \\
\hline sediment trap & $\begin{array}{l}\text { geotextile filter below structural ele- } \\
\text { ments, geosynthetic bag material }\end{array}$ \\
\hline
\end{tabular}

The "passive" option is to protect the ground, permanently or only as long as vegetation is developing. Mulching is often proposed to shelter the bare ground surface to avoid erosion und to support vegetation growth. To protect the light mulch material against dislocation and wind erosion, synthetic grids of thin threads are often sufficient (Figure 5).

Instead of mulch, a geotextile fabric can protect an erosion susceptible surface. If protection is needed only temporarily, for many applications natural fibres can be used. Such fibres will disintegrate after a certain time, but may remain strong enough until vegetation has grown.

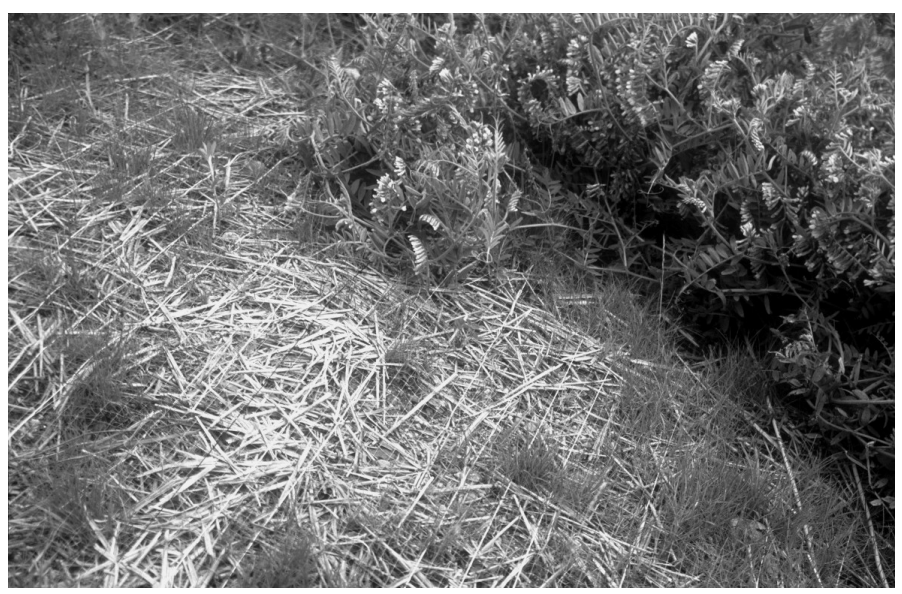

Figure 5: Mulch secured with thin geogrid

\section{EROSION PROTECTION FOR FLOOD AND STORMWATER DISCHARGE}

If the hydraulic load on the ground is very strong, e.g. fast flowing flood discharge or storm precipitation, or if local boundary conditions are adverse to the natural development of vegetation, geosynthetic erosion protection mats (turf reinforcement mats) may help. With such a "soft armour" system, roots are able to establish and finally stabilize the soil. Due to steepness or wind impact, an erosion protection sheet might need to be fixed to the ground, commonly by means of pins (usually on a $1 \times 1 \mathrm{~m}$ grid) to ensure proper contact of mat and ground. If pinning is not possible, the fabric has to be anchored in ditches at the top of the slope. For such applications, products have to be used that provide the tensile strength needed. For reliable seeding, erosion protection mats can be filled with seed. Performance can be increased through combination with soil or stone chippings within the fabric or even with a bitumen-bonded filter fill in the erosion protection mat. A combination with hydroseeding is also possible. Theisen (1992) gives possible design velocities for uncovered ground and soft armour with and without vegetation (Figure 6). It is important to notice that the protection effect decreases with the duration of the flow.

If protection with more strength is needed, for example to protect foundations, geotextile containers can provide the necessary stability. Installed to protect the plinths of houses, reinforcement of the foundation as well as strength of the water-loaded surface is achieved. Also pylons and poles in the flood basin are prone to scour around their foundations. Local protection around such structures can be perfectly done by geosynthetic containers. Such elements have to be heavy enough, not to be transported by the current. The fabric used should be chosen as a filter towards the fill and towards the ground material. To provide shelter against UV radiation, the containers 
should be covered by sand or topsoil that may be eroded during the flood but can be replaced easily after a flood. The geotextile has to be abrasion resistant because of the sediment transport during flooding. Also general robustness is needed not to be damaged by the debris transported in with the flood. Containers offer the additional advantage that often local fill material can be used as fill and no extra material has to be provided.

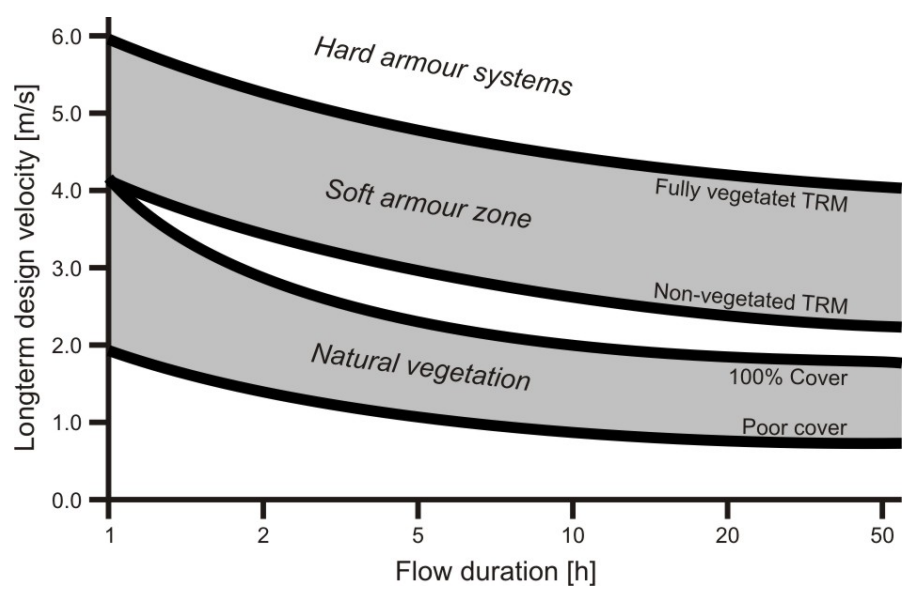

Figure 6. Design velocities for vegetation and armour (Theisen, 1992).

For bank and slope protection against erosion, increasingly effort is put into bioengineering solutions, i.e. the integration of vegetation. Vegetative elements can be used in areas that are only temporarily drowned or loaded by hydraulic actions. Often grass is used to provide a certain erosion protection.

For stronger resistance pre-vegetated gabion-like structures are used with success. An example is the use of elements, where the core is made of heavy stones to guarantee stability in combination with lava material to keep sufficient moisture for the plants during dry periods. Between stone fill and gabion mesh, a filter is needed (Figure 7, left).
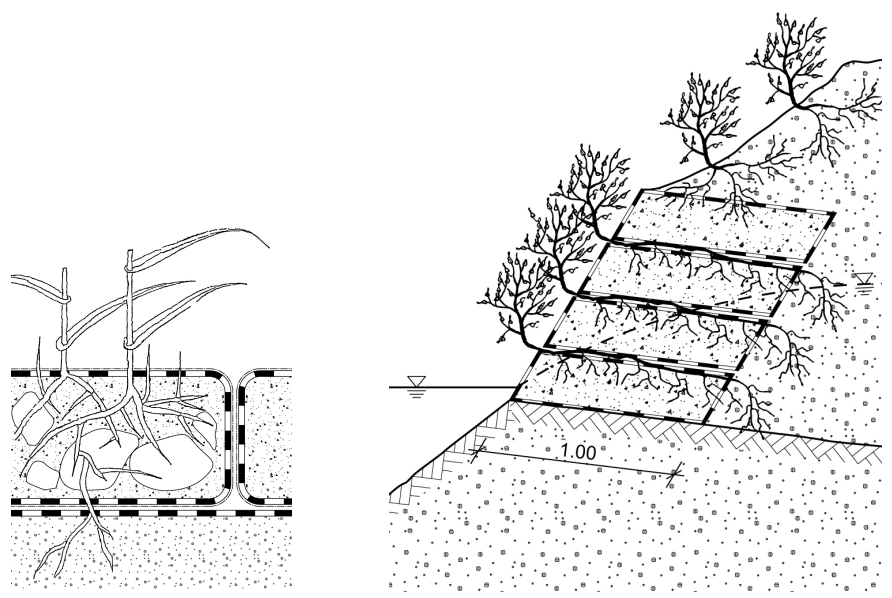

Figure 7. Vegetated containers (left); stacked containers with willow saplings (right).
Very strong protection can be build combining stacked gabions (including a well-designed filter), containers, tubes or wrapped-around solutions with plants in between, predominantly willows. The geosynthetic elements provide erosion protection of the subsoil while the plants act as "ground anchors" of the whole system (Figure 7, right). Additionally they grant the protection of the geosynthetic fabric against weathering. Even though "green solutions" are desirable, it is safety that has to be focused on. So often the best solution is to combine the technical solution and vegetative elements (Heibaum 2012).

\section{OVERTOPPING}

Dikes (also referred to as levees) aren't necessarily designed to hold back every conceivable flood, and they might not perform perfectly even when they are faced with routine floods, e.g. when unexpected settlement occurs or debris blocks spillways. On the other hand, flood risks are assumed to increase because of more intense rainfall, stronger wind speeds and increases sea levels. Therefore it might be advantageous to design the dike or levee for possible overtopping.

Overtopping of an earth structure like a dike or embankment can create erosion damage on the crest and the rear face if the discharge exceeds $1-10 \mathrm{l} / \mathrm{s} / \mathrm{m}$ and the surface is covered by grass, but only 0.1 $1 / \mathrm{s} / \mathrm{m}$ if there is no protection of the surface (EurOTop 2007). Overtopping can also create slip failure which will lead to a breach even faster than erosion. Such slip failures occur mainly for slopes steeper than $1: 3$, so nowadays most dikes are built with a landward slope of 1:3 or flatter.

A flood event in a river does not necessarily mean that the whole course of the river is threatened equally. The severe floods of the river Mississippi in 2008 showed that while a 1000 -year flood took place at one place, only a 13-year flood occurred approximately $225 \mathrm{~km}$ downstream (Bernhardt et al. 2011).

Overtopping often sides with saturation of the dike, which weakens the structure generally and which makes it easier for the overtopped water to cut into the slope surface or into the toe of the dike, regressing to the crest unless creating a breach. The degree of such a process is dependent on the depth and duration of the overtopping as well as the soil properties. The velocity of the flow in the direction of the main axis of the river is usually much lower than the velocity of the overtopping flow perpendicular to the main axis that can reach $10 \mathrm{~m} / \mathrm{s}$.

The primary shelter of dikes and embankments against hydraulic loads is the grass cover. But to act successfully, a dense cover with well-developed sod is required. Bernhardt et al. (2011) report that in damaged areas after the Mississippi flood most of the grasses present were annual weeds rather than 
sod forming grasses. Such weeds are only present for a portion of the year and tend to clump leaving spaces where the soil surface is bare. In springtime such weed can be very invasive and can take over an area, but because it is an annual plant it will die out during a freeze. Therefore such cover cannot be considered as a protective armoring. In other places some types of grass survived the continuous flow of water and had a positive impact on preventing erosion. Additionally the flow forces laid the grass down, creating a protective cover on top of the soil surface.

Temple et al. (1987) discuss the possible erosion mechanism in grass-lined channels. It is observed that soil particle detachment can begin at low stresses that do not affect vegetation. But as the soil particles are removed, the vegetation is undercut and the weaker vegetation is removed. This way the density and uniformity of the cover is decreasing with the result of an increased erosion rate. A conforming observation was made during the overtopping tests in the ComCoast project ("Combined functions in the coastal zone" - European Interreg IIIB project 20022007 with partners in The Netherlands, Denmark, Germany, Belgium and the UK). These tests showed that if there is one hole in the grass surface, more erosion will follow in a zipper effect. So roots alone provide not sufficient shelter against erosion. In the ComCoast tests, the grass cover was stable until a discharge of $30 \mathrm{l} / \mathrm{s} / \mathrm{m}$ or even $50 \mathrm{l} / \mathrm{s} / \mathrm{m}$ (Van der Meer 2008). But it has to be pointed out that the ground was unsaturated. After a long flood period, the dike body would be saturated which increases the vulnerability significantly. Furthermore it was realized that transitions from crest to slope are most susceptible to damage.

To increase the resistance in many cases stone revetments or a layer of open asphalt are installed. Such layers are often covered with soil, allowing grass to grow on it so as to make the dike look 'green' again. A much more elegant solution can be provided by geosynthetic systems.

There are several methods to introduce geosynthetics to the flow resisting system. Threedimensional erosion protection mats can be used like discussed above as countermeasure against surface erosion. Within the ComCoast project a grass reinforcement system (Smart Grass Reinforcement, abbreviated SGR) has been developed and tested (Van Gerven \& Akkermann 2006). In this system a geosynthetic grid is placed a few centimeters below the surface to strengthen the grass sod. In case that the grass cover is not flawless or hydraulic impact has locally removed the grass, the geosynthetic grid bridges the bare spot. Ideally the grid is installed from the very beginning. But since often strengthening is required for an existing dike with grass cover, a method was developed to place the geotextile fabric below an existing grass cover. (Certainly it needs some time to let the lifted roots grow through the grid into the ground below.) During the field tests, the SGR proved to function very well. However, large scale installation of the SGR awaits still some further development when applied at existing dikes. This method reinforces the grass armour, the retention of soil particles is provided only by sufficiently closely spaced roots of the sod.

Another approach to build scour-resistant dikes and levees is outlined in Haselsteiner et al. (2008) and PIANC (2011). The general idea is to sacrifice a certain top layer, but to keep the core erosion resistant. In the case that the grass cover is not strong enough, grass and top soil would be washed away, but erosion can't go further due to geotextile elements that hinder erosion and ensure overall stability. This can be achieved by wrapping the embankment material, either using geosynthetic containers of a size that would be large enough to withstand hydraulic loads and impacts, or a "wrapped around" method is chosen (Figure 8), where a geotextile sheet enfolds soil layers of limited thickness. A layer of geotextile is spread and sand is placed on top of it, typically between $0.3 \mathrm{~m}$ and $1.0 \mathrm{~m}$ in vertical height. The loose end of the geotextile is then folded back and a second geotextile layer is laid on top and the procedure is repeated. This construction method will protect the embankment against all possible impact: bank scour will affect only the soil cover on top of the geotextile, any internal erosion due to percolation will be stopped by the filter function and overtopping will cause only erosion of the top soil but the core will remain stable.

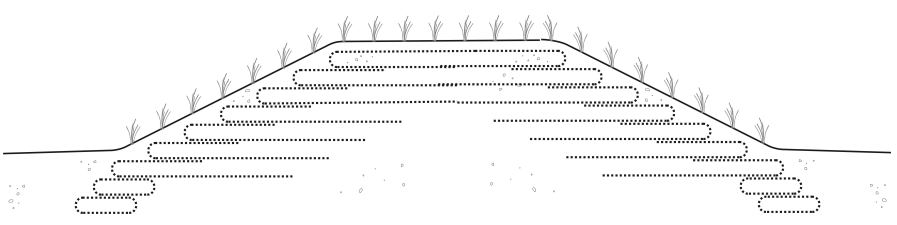

Figure 8. Wrap-around-method for dike protection.

\section{CONCLUSION}

Nature often demonstrates the power of water to be stronger than soil and vegetation, often even stronger than rock. Even seemingly mild hydraulic load from rainfall can be the reason for severe impact on structures and ground. Surface erosion is an extraordinary threat to all earthen structures, because initially only tiny rills can develop to deep gullies or channels, which can reduce their stability. And intense rainfall can be the reason for debris transport, hill slides and mud avalanches that block transport infrastructure and watercourses.

To achieve erosion mitigation or to hinder erosion at all, either the action of the water has to be reduced or the resistance of the ground and man-made earth structures has to be increased. The first results in controlling, the second in opposing the water. 
Due to intense rainfall sheet and rill erosion develop, and following flow concentration, gully and channel erosion occur that may finally lead to failure of an earth structure. Flooding causes erosion at the upper bank, i.e. in areas significantly above the normal high water level, but where hydraulic impact must be expected even though the repetitiveness is not high. Overtopping of an earth structure like a dike or embankment can create erosion damage on the crest and the downstream face. Overtopping often sides with saturation of the dike, which weakens the structure generally and which makes it easier for the overtopped water to cut into the slope surface or into the toe of the dike, regressing to the crest unless creating a breach.

Countermeasures to rainfall runoff are agricultural measures like disking or contour ploughing, or structural measures like terracing or building checks in erosion rills and gullies. Vegetation stabilizes the surface, but may need protection, at least during growth. therefore often additional measures are necessary. Since hard armour often contradicts the idea of natural appearance, soft armour systems are desirable.

Geosynthetic sheets or containers contribute appropriate solutions in these cases. For erosion prevention many geosynthetic systems are available, providing shelter to the ground against raindrop and runoff erosion as well as against severe scouring. Geosynthetics also provide appropriate reinforcement of an earthen structure to increase the resistance against failure even in case of surface erosion. Any countermeasure should be done as early as possible in the course of flowing water. For these purposes the flexibility of geosynthetics is of major importance to adapt tightly to the ground and its possible deformations. And finally it should be recognized very clearly that in every application, careful design and the use of robust material are essential.

\section{REFERENCES}

Bernhardt, M., Briaud, J.L., Kim, D., Leclair, M., Storesund, R., Lim, S.G., Bea, R.G., Rogers, J.D., (2011). Mississippi River Levee Failures: June 2008 Flood. International Journal of Geoengineering Case Histories Vol.2, Issue 3, p. 127162.

Eur0top (2007): Wave Overtopping of Sea Defences and Related Structures: Assessment Manual - Die Küste, Heft 73. $178 \mathrm{p}$.

Haselsteiner, R.; Strobl, T.; Heerten, G.; Werth, K. (2008): Overflow Protection Systems of Flood Embankments With Geosynthetics. Proceedings 4th European Geosynthetics Conference, Edinburgh September 7-10, 2008 (EuroGeo4), Paper Nr. 50.

Heibaum, M. (2012): Combining Plants, Natural and Artificial Building Material for the Optimal Protection of Banks and Coasts. International Conference on Scour and Erosion ICSE6, Paris, August 27-31.
Heibaum, M. (2014): Rethinking geotextile filter design. Proc. 10th International Conference on Geosynthetics (10ICG), September 21-25, 2014, Berlin, Germany. paper 142; 8 pp.

Holtz, R. D., Christopher, B. R., Berg, R. R. (1997): Geosynthetic engineering. BiTech Publishers Ltd., Richmond, BC, Canada, $451 \mathrm{p}$.

Johnson, A. Moffatt, A., Slattery, E (2003): Erosion control handbook for local roads. Minnesota Local Road Research Board, Manual No. 2003-08.

North Dakota Department of Transport (2004): The Erosion and Sediment Handbook.

PIANC (2011): Application of geotextiles in waterfront protection, Report No.113, Working Group 56, PIANC, MarCom, $110 \mathrm{p}$.

Temple, D.M., K.M. Robinson, R.M. Ahring, A.G. Davis. (1987): Agriculture Handbook 667, Stability Design of Grass-Lined Open Channels. USDA-Agricultural Research Service.

Theisen, M. S. (1992): The Role of Geosynthetics in Erosion and Sediment Control: An Overview. Geotextiles and Geomembranes 11, 535-550

Van der Meer, J. (2008): Erosion strength of inner slopes of dikes against wave overtopping. Report in the framework of the ComCoast Project.

Van Gerven, K.A.J.; Akkerman, G.J. (2006): Placement of Smart Grass Reinforcement at Test Sections Groningen Sea Dyke. Final report in ComCoast Workpackage 3, Development of Alternative Overtopping-Resistant Sea Defences.

Zejun, T.; Tingwu, L.; Qingwen, Z.; Jun, Z. (2002): The Sealing Process and Crust Formation at Soil Surface under the Impacts of Raindrops and Polyacrylamide. 12th International Soil Conservation Organization (ISCO) Conference, May 26-31, 2002. Ministry of Water Resources, Beijing, China. 